\title{
A draft genome sequence and functional screen reveals the repertoire of type III secreted proteins of Pseudomonas syringae pathovar tabaci I I528
}

\author{
David J Studholme*1, Selena Gimenez Ibanez ${ }^{1}$, Daniel MacLean ${ }^{1}$, \\ Jeffery L Dangl ${ }^{2}$, Jeff H Chang ${ }^{3,4}$ and John P Rathjen ${ }^{1}$
}

\begin{abstract}
Address: ${ }^{1}$ The Sainsbury Laboratory, Norwich, NR4 7UH, UK, ${ }^{2}$ Department of Biology, CB\# 3280, Coker Hall, The University of North Carolina at Chapel Hill, Chapel Hill, North Carolina 27599-3280, USA, ${ }^{3}$ Department of Botany and Plant Pathology, Oregon State University, 2082 Cordley Hall, Corvallis, OR 97331, USA and ${ }^{4}$ Center for Genome Research and Biocomputing, Oregon State University, 2082 Cordley Hall, Corvallis, OR 97331, USA

Email: David J Studholme* - david.studholme@tsl.ac.uk; Selena Gimenez Ibanez - selena.gimenez-ibanez@tsl.ac.uk; Daniel MacLean - dan.maclean@tsl.ac.uk; Jeffery L Dangl - dangl@email.unc.edu; Jeff H Chang - changj@cgrb.oregonstate.edu; John P Rathjen - john.rathjen@tsl.ac.uk

* Corresponding author
\end{abstract}

BMC Genomics 2009, 10:569 doi:10.1186/147|-2164-10-569

This article is available from: http://www.biomedcentral.com/I47I-2/64/I0/569

(c) 2009 Studholme et al; licensee BioMed Central Ltd.

This is an Open Access article distributed under the terms of the Creative Commons Attribution License (http://creativecommons.org/licenses/by/2.0), which permits unrestricted use, distribution, and reproduction in any medium, provided the original work is properly cited.

\section{Correction}

After the publication of this work [1], we became aware of several errors in our descriptions of proteins associated with the type III secretion system (T3SS) of $P$. syringae pathovar tabaci (Pta) strain 11528.

As mentioned in the text of the article [1], Pta 11528 encodes a full-length homologue of HopAB2. Therefore, in Figure 1, HopAB2 should not have been marked with asterisks. A corrected summary of the Hop protein repertoire in Pta 11528 is shown in Figure 1 of this Correction. We confirmed the presence of a full-length hopAB2 using capillary sequencing. Unfortunately, in the draft assembly of Illumina sequence data presented in the paper [1], there was a mis-assembly error that resulted in deletion of 271 nucleotides from the 5' end of the hopAB2 gene. This type of error is, unfortunately, not uncommon in assemblies of short sequence reads, though recent versions of the Velvet assembly software seem to be less prone to such errors. We are currently generating 454 GS-FLX sequence data from Pta 11528 genomic DNA and hope to make public an improved genome assembly and annotation in due course.
Pta 11528 encodes a full-length homologue of T3SS helper protein HrpA2 (Locus tag C1E_5326 in our annotation; RefSeq: ZP_05641290.1). Therefore hrpA2 should have been shown in boldface and underlined in Figure 1 of the manuscript [1]. This has been remedied in Figure 1 of this Correction

Contrary to the original manuscript [1], HopR1 is degenerate in Pta 11528. In the Pta 11528 draft assembly, the hopR1 gene was split into at least two open reading frames (RefSeq: ZP_05639788.1，ZP_05639787.1; locus tags C1E_3889, C1E_3890) suggesting that is a degenerate pseudogene. We confirmed the presence of an internal stop codon in hopR1 using capillary sequencing. This degeneracy should have been indicated by marking hopR1 with a double asterisk $\left({ }^{* *}\right)$ in Figure 1 . This has been remedied in Figure 1 of this Correction

Pta 11528 encodes a full-length HopM1 homologue (RefSeq: ZP_05641297.1; locus tag C1E_5336; GenBank: ACR46722.1). The fact that HopM1 is intact and not degenerate should have been indicated in Figure 1 (by highlighting hopM1 in boldface and underlined) in the 


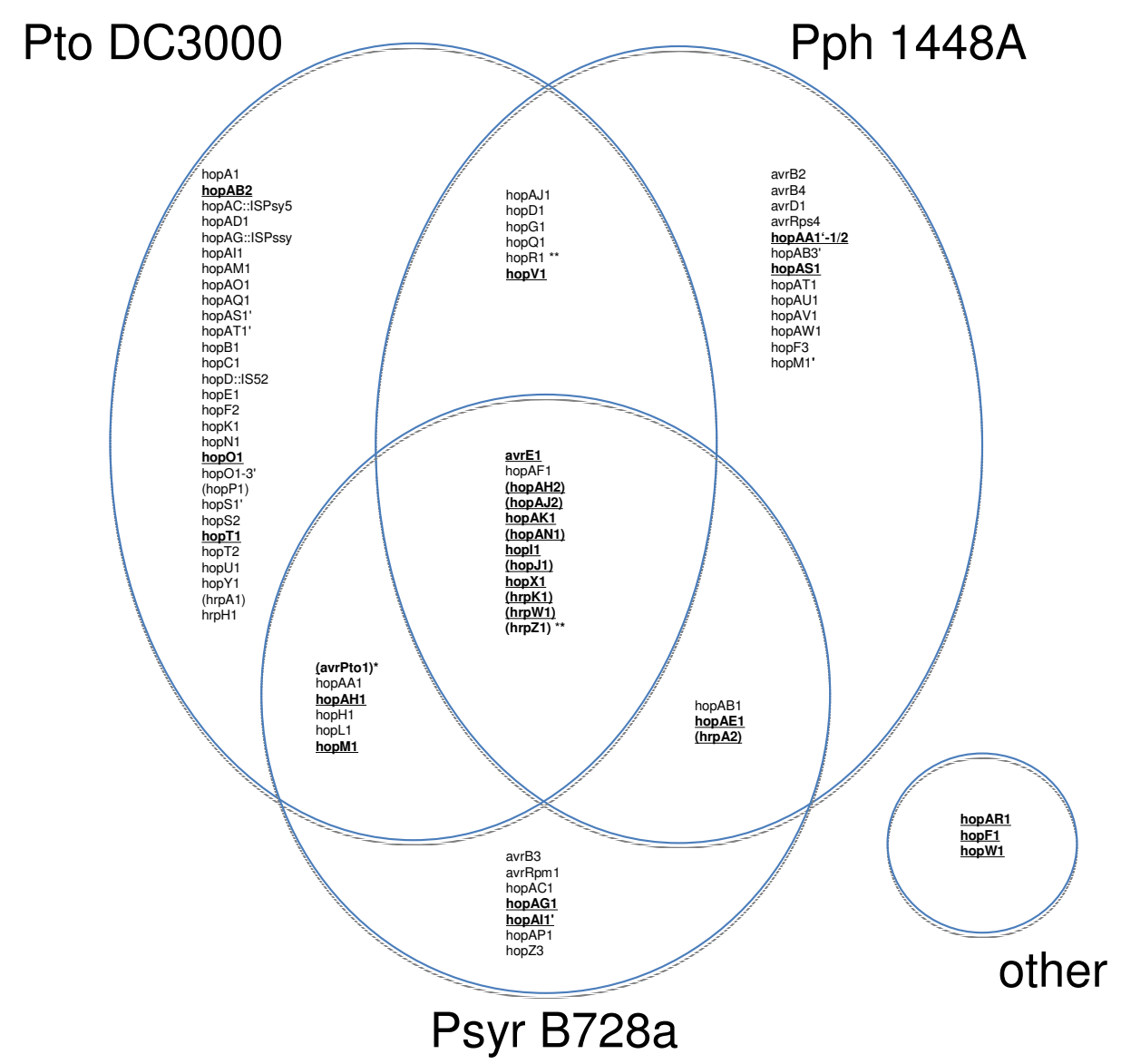

Figure I

Comparison of the complement of Pta I I 528 genes encoding candidate T3SS substrates with those of the three fully sequenced $\boldsymbol{P}$. syringae genomes. In addition to validated hop genes, also are included are several genes for T3SS helper proteins ( $h r p A I, h r p A 2, h r p Z I, h r p W I, h r p K I$ and hopPI) and several former candidates that are probably not true hop genes (hopAH2, hopJI, hopAJ2 and hopANI) (the HopDB website, http://www.pseudomonas-syringae.org); these genes are indicated by parentheses. Those genes that are conserved in Pta II528 are shown in boldface and underlined. Pta II528 also contains three hop genes that do not have orthologues in the three sequenced genomes: hopARI, hopFI and hopWI. * No close homologue of avrPto I was found in Pta I I528; however, there is a gene encoding a protein that shares $43 \%$ amino acid identity with AvrPtol from Pto DC3000. ** In the Pta II 528 genome hrpZI and hopRI appear to be degenerate pseudogenes.

original manuscript [1]. This has been remedied in Figure 1 of this Correction.

We regret any inconvenience caused by these errors and are grateful to Dr Magdalen Lindeberg for bringing them to our attention.

\section{References}

I. Studholme DJ, Ibanez SG, MacLean D, DangI JL, Chang JH, Rathjen JP: A draft genome sequence and functional screen reveals the repertoire of type III secreted proteins of Pseudomonas syringae pathovar tabaci II 528. BMC Genomics 2009, 10:395.
Publish with BioMed Central and every scientist can read your work free of charge

"BioMed Central will be the most significant development for disseminating the results of biomedical research in our lifetime. "

Sir Paul Nurse, Cancer Research UK

Your research papers will be:

- available free of charge to the entire biomedical community

- peer reviewed and published immediately upon acceptance

- cited in PubMed and archived on PubMed Central

- yours - you keep the copyright

Submit your manuscript here:

http://www.biomedcentral.com/info/publishing_adv.asp 